\title{
PELAKSANAAN KEWENANGAN PEMERINTAHAN TERHADAP OTONOMI DESA DI DESA CARAWALI KECAMATAN WATANG PULU KABUPATEN SIDENRENG RAPPANG
}

\author{
Nursiah Sidi \\ Fakultas IImu Sosial dan IImu Politik,Universitas Muhammadiyah Sidenreng Rappang \\ Nursiahsidi43151083f1@gmail.com
}

\begin{abstract}
Abatrak
Penelitian ini bertujuan Untuk Mengetahui Pelaksanaan Kewenangan Pemerintahan terhadap Otonomi Desa di Desa Carawali Kecamatan Watang Pulu Kabupaten Sidenreng Rappang dan Untuk Mengetahui Seberapa Besar Pelaksanaan Kewenangan Pemerintahan terhadap Otonomi Desa di Desa Carawali Kecamatan Watang Pulu Kabupaten Sidenreng Rappang Populasi dalam penelitian ini adalah seluruh penduduk yang terdaftar sebagai masyarakat di Desa Carawali Kecamatan Watang Pulu yaitu berjumlah 2.207 jiwa. Teknik pengambilan sampel menggunakan rumus Slovin dengan hasil yaitu 96 responden, diambil berdasarkan teknik Random Sampling yaitu sampel acak dari populasi keseluruhan masyarakat.Tipe penelitian ini adalah Deskriptif Kuantitatif.Teknik pengumpulan data yang digunakan dalam penelitian ini adalah Observasi, Wawancara, koesioner dan Studi Kepustakaan. Data yang terkumpul kemudian digunakan dengan cara teknik analisis data, dengan menggunakan tabel Frekuensi dan Skala Likert.Hasil penelitian ini menunjukkan Pelaksanaan Kewenangan Pemerintahan terhadap Otonomi Desa di Desa Carawali Kecamatan Watang Pulu Kabupaten Sidenreng Rappang bahwa sebesar 70\% dari 100\% dari hasil yang diharapkan, dimana ini tergolong dalam kategori baik. Adapun faktor-faktor yang memengaruhi pelaksanaan kewenangan dipengaruhi tidak adanya implementasi pembagian kewenangan pemerintahan di Desa Carawali Kecamatan Watang Pulu Kebupaten Sidenreng Rappang adalah $71 \%$ dari $100 \%$ dari hasil yang diharapkan dimana tergolong dalam kategori baik.
\end{abstract}

Kata Kunci :Kewenangan, Pemerintahan Desa dan Otonomi Desa

\begin{abstract}
This study aims to determine the implementation of government authority over village autonomy in the village Carawali District of Watang Pulu District of Sidenreng Rappang and to find out how much the exercise of government authority over village autonomy in the village of Carawali District of Watang Pulu District of Sidenreng Rappang the population in the this study is the entire population registered as comunities in Carawali village District of Watang Pulu totaing 2,207 people. The sampling techniques uses the slovin formula with the results of 96 respondents, tekan based on a random sampling technique that is a random sample of the eutire population of the communty. Data collection techniques used $i$ this study were observation, interviews, questionnaires, and library studies. The collected data is then used by means of dat analysis, using frequency table and litert scales. The resolts of this study show the implementation of government authorty in the village Carawali District of Watng Pulu District of Sidenreng Rappang that $70 \%$ of $100 \%$ of the oxpected results, whisch is classified as good. As for the factors that influence the exrase of authority influnced by the absence of implmentation of the devision of goverment authority in the village Carawali District of Watang Pulu District of Sidenreng Rappang is $71 \%$ of $100 \%$ of the expected results which are in the good category.
\end{abstract}

Keywords: Authority, Village Government, and Village Autonomy

PRAJA| Volume 8| Nomor 2| Edisi Juni 2020 


\section{A. PENDAHULUAN}

Otonomi Desa merupakan otonomi yang asli, bulat dan utuh serta bukan merupakan pemberian dari pemerintah. Sebaliknya pemerintah berkewajiban menghormati otonomi asli yang dimiliki olehDesa tersebut. Sebagai kesatuan masyarakathukum yang mempunyai susunan asliberdasarkan hak istimewa, desa dapatmelakukan perbuatan hukum baik hokumpublik maupun hukum perdata, memiliki kekayaan, harta benda serta dapatditentukan dan menuntuk dimuka pengadilan. Lahirnya Undang-Undang No 6 tahun 2014 tentang Desa menyelenggarakan pemerintahan yang ada di desa menurut asas otonomi. Dalam hal ini untukmengoptimalkan penyelenggaraan perintahan desa maupun fungsi pemerintahan yang lain seperti pemberdayaan masyarakat desa, pembangunan desa, dan desa semua aparatur pemerintah tersebut dapat bersinergi dan bekerja sama dengan baik, serta tepat dalam meningkatkan penyelenggaraan pemerintahan desa yang profesional dan akuntabel.

Perlunya keberhasilan pelaksanaan Otonomi Desa ditandai dengan semakin mampunya Pemerintah Desa memberikan pelayanan kepada masyarakat dan membawa kondisi masyarakat ke arah kehidupan yang lebih baik, dengan terselenggaranya Otonomi Desa, maka hal itu akan menjadi pilar pentingOtonomi Daerah, keberhasilan Otonomi Daerah sangat ditentukan oleh berhasil tidaknya Otonomi Desa, pemerintah daerah diharapkan mampu membuka peluang memajukan daerahnya dengan melakukan identifikasi sumber-sumber pendapatan dan mampu menetapkan belanja daerah secara efisien, efektif, dan wajar.

Penyelenggaraan urusan pemerintahan yang dilaksanakan oleh Pemerintah Desa dan Badan Permusyawaratan Desa yaitu untuk mengatur dan mengurus kepentingan masyarakat setempat berdasarkan asal-usul dan adat istiadat setempat yang diakui dan dihormati dalam memperoleh pelayanan yang sama dan adil, menyampaikan aspirasi, bertanggung jawab tentang kegiatan penyelenggaraan pemerintahan desa, pelaksanaan pembangunan desa, pembinaan kemasyarakatan desa, dan pemberdayaan masyarakat desa Sistem Pemerintahan Negara Kesatuan Republik Indonesia, Sejalan dengan prinsip tersebut dilaksanakan pula prinsip otonomi nyata dan bertanggung jawab, prinsip otonomi nyata adalah suatu prinsip bahwa untuk menangani urusan pemerintahan dilaksanakan berdasarkan tugas dan wewenang dan kewajiban yang senyata telah ada dan berpotensi untuk tumbuh, hidup dan berkembang sesuai dengan potensi dan kekhasan daerah. Pemerintah desa merupakanpelaksana dari otonomi desa, dengan adanya otonomi desa pemerintah desa mempunyai wewenang untuk menjalankan otonomi desa dengan penuh termasuk melakukan pendampingan dalam perencanaan, pelaksanaan, dan pemantauan pemberdayaan masyarakat, dengan demikian isi dan jenis otonomi bagi setiap daerah tidak selalu sama dengan daerah lainnya, sedangkan yang dimaksud dengan otonomi yang bertanggung jawab adalah otonomi yang dalam penyelenggaraanya harus benar-benar sejalan dengan tujuan dan maksud pemberian otonomi, yang pada dasarnya untuk memberdayakan daerah termasuk meningkatkan kesejahteraan rakyat.

Berdasarkan penggamatan awal, peneliti menemukan masalah mengenai aparatur pemerintah desa belum optimal yang bersinergi dan bekerja sama dengan baik senada yang dikatakan oleh salah satu warga masyarakat desa carawali dalam hal penyelenggara Pemerintahan Desa belum terlaksana apa yang menjadi harapan Desa, tidak cukup satu dekade diterbitkan lagi UU Nomor 6 tahun 2014 sebagai pengganti Undang - Undang sebelumnya, namun apa yang terjadi di Desa tidak terlalu banyak perubahan. Penerapan hak,kewajiban dan kewenangan pemerintah untuk mengatur dan mengurus kepentingan masyarakat setempat dalam hal penerapan otonomi desa yang belum sesuai, hal ini dikarenakan rendahnya faktor kemampuan aparatur pemerintah desa sehingga dalam penyelenggaraan tugas dan fungsi kepala desa dalam penetapan peraturan di desa belum maksimal. misalnya jam masuk kantor. Dengan demikian, Pemerintah Desa adalah para penyelenggara dalam rangka mengatur 
dan mengurus kepentingan masyarakat, sehingga dapat meningkatkan kemampuan desa yang profesional, akuntabel dan potensi. Berdasarkan uraian di atas, penelitian tertaris untuk meneliti dengan judul "Pelaksanaan Kewenangan Pemerintahan terhadap Otonomi Desa di Desa Carawali Kecamatan Watang Pulu Kabupaten Sidenreng Rappang" dengan tujuan untuk mengetahui Pelaksanaan Kewenangan Pemerintahan terhadap Otonom Desa di Desa Carawali Kecamatan Watang Pulu Kabupaten Sidenreng Rappang dan untuk mengetahui faktor-faktor apa yang mempengaruhi Pelaksanaan Pewenangan Pemerintahan terhadap Otonomi Desa di Desa Carawali Kecamatan Watang Pulu Kabupaten Sidenreng Rappang.

\section{Konsep Kewenangan}

Menurut H.D Stout wewenang adalah pengertian yang berasal dari hukum organisasi pemerintahan, yang dapat dijelaskan sebagai seluruh aturan-aturanyang berkenaan dengan perolehan dan penggunaan wewenang-wewenang pemerintahan oleh subjek hukum publik didalam hubungan hukum publik.( Ridwan HR 2013:71). Berbicara kewenangan memang menarik, karena secara alamia manusia sebagai mahluk social memiliki keinginan untuk diakui ekstensinya sekecil apapun dalam suatu komunitasnya, dan salah satu factor yang mendukung keberadaan ekstensi tersebut, Menurut Prajudi atmosudirdjo, membedakan antara wewenang (competence, bevoegdheid) dan kewenangan (author, gezag). Walaupun dalam prakteknya perbedaan tidak selalu perlu. Kewenangan apa yang disebut kekuasaan formal, kekuasaan yang berasal dari kekuasaan legislative (diberi oleh undang-undang) atau dari kekuasaan eksekutif administrative (Prajudi Atmosudirdjo, 1995:78). Tipe kewenangan, yaitu :

1. Kewenangan Prosedural, yaitu berasal dari Peraturan Perundang-undangan.

2. Kewenangan Substansial, yaitu berasal dari tradisi, kekuatan sacral, kualitas pribadi dan instrumental.

Undang-undang Nomor 23 Tahun 2014 Tentang Pemerintahan Desa Pasal 1 Desa adalah Desa dan adat atau yang disebut dengan nama lain, selanjutnya disebut adalah kesatuan masyarakat hukum yang memiliki batas wilayah yang berwenang untuk mengatur dan mengurus urusan pemerintahan, kepentingan masyarakat setempat berdasarkan prakarsa masyarakat, hak asal usul, dan/atauhak tradisional yang diakui dan dihormati dalam sistem pemerintahan Negara Kesatuan Republik Indonesia,

Desa menurut undang-undang nomor 6 tahun 2014 tentang desa, mengartikan desa sebagai berikut:

"Desa atau yang disebut nama lain, selanjutnya disebut desa, adalah kesatuan masyarakat hukum yang memiliki batasbatas wilayah yang berwenang untuk mengatur dan mengurus kepentingan masyarakat setempat, berdasarkan asalusul dan adat istiadat setempat yang diakui dan dihormati dalam sistem pemerintahan Negara Kesatuan Republik Indonesia (UU No. 6 Tahun 2014 tentang desa pasal 1 ayat 1$)$.

Pengertian desa menurut Widjaja dan Undang-Undang Nomor 6 Tahun 2014 di atas desa merupakan komunitas yang mengatur dirinya sendiri.Dengan pemahaman bahwa desa memiliki kewenangan untuk mengatur dan mengurus kepentingan masyarakat sesuai dengan kondisi dan sosial budaya setempat, maka posisi desa yang memiliki otonomi asli sangat strategis sehingga memerlukan perhatian yang seimbang terhadap penyelenggaraan otonomi desa.karena dengan otonomi desa yang kuat akan mempengaruhi secara signifikan perwujudan otonomi daerah. Pelaksanaan otonomi desa di pertegas dalam Undang-Undnag Nomor 6 Tahun 2014 Pasal 81:

a). Pembangunan Desa dilaksanakan sesuai dengan Rencana Kerja Pemerintah Desa.

b). Pembangunan Desa sebagaimana dimaksud pada ayat (1) dilaksakan oleh pemerintah Desa dengan melibatkan seluruh masyarakat Desa dengan semangat gotong royong.

c). Pelaksanaan pembangunan Desa sebagaimana dimaksudkan pada ayat (1) dilakukan dengan memanfaatkan kearifan lokal dan sumber daya alam Desa. 
d). Pembangunan lokal berskala Desa dilaksanakan sendiri oleh Desa.

e). Pelaksanaan program sektor yang masuk ke Desa diinformasikan kepada Pemerintah Desa untuk diintegrasikan dengan pembangunan Desa.

Tujuan Pembentukan Desa adalah untuk meningkatkan kemampuan penyelenggaraan pemerintahan secara berdaya guna dan hasil guna dan peningkatan pelayanan terhadap masyarakat sesuai dengan tingkat perkembangan dan kemajuan pembangunan.

\section{Faktor-faktor yang mempengaruhi Implementasi Kebijakan}

Menurut ( Haryanto: 2006) Faktor-faktor yang menjadi kendala tidak adanya implementasi pembagian kewenangan itu sendiri, yakni menyangkut:

a. Belum adanya aturan hukum yang memadai yag menjadi dasar pembagian kewenangan. Oleh karena itu implementasi pun juga belum ada. Jika di desa telah dilaksanakan kewenangankewenangan, hal itu semata-mata didasarkan pada rutinitas sebelumya.

b. Kemampuan perangkat desa maupun anggota BPD relatif terbatas baik dalam hal tingkat pendidikan formal, kemampuan khusus terkait dengan tuntutan juga fungsinya maupun pemamahan terhadap kewenangan desa itu sendiri.

c. Tingkat penghasilan para perangkat desa dan anggota BPD belum memadai sehingga mengakibatkan dedikasi kerja tidak optimal.

\section{B. METODE PENELITIAN}

Tipe penelitian deskriptif kuantitatif, dengan metode ini diharapkandapat memberikan gambaran secara cermat, jelas dan objektif mengenai masalah yang sedang diteliti.. Sedangkan dasar penelitian yang dilakukan adalah survei dimana kegiatanpenelitian menggunakan kuisioner/wawancara sebagai instrument utama dalam pengumpulan data dilapangan.

Menurut Sugiyono pengertian populasi adalah wilayah generalisasi yang terdiri atas objek/subjek yang mempunyaai kualitas dan karakteristik tertentu yang ditetapkan oleh peneliti untuk dipelajari dan kemudian ditarik kesimpulannya (Sugiyono, 2011). Populasi adalah keseluruhan obyek penelitian.Apabila seseorang ingin meneliti semua elemen di wilayah penelitian, maka populasi dalam penelitian ini adalah masyarakat desa carawali dengan jumlah populasi 2.207 jiwa. Teknik penarikan sampel adalah Probality Sampling. Probality Sampling adalah teknik pengambilan sampel yang memberikan peluang atau kesempatan yang sama bagi setiap unsur atau anggota populasi untuk dijadikan menjadi sampel.Teknik Probality Sampling yang digunakan dalam pengambilan sampel pada peneliti ini lebih tepatnya peneliti menggunakan teknik Random Sampling atau sampel acak dari populasi keseluruhan masyarakat yang ada di Desa Carawali. Teknik pengambilan sampel menggunakan rumus Slovin. maka sampel 3orang di dusun cenrana, 48 orang di dusun carawali , maka jumlah keseluruhan 96 orang masyarakat desa Carawali Kecamatan Watang Pulu yang menjadi responden.

Teknik pengumpulan data yang digunakan adalah Observasi, Studi Kepustakaan, Quisioner (angket), dan Wawacara (Interview). Sedangkan teknik analisis Data diperoleh melalui kuesioner dianalisis dengan melalui skala Litert.Menurut Sugiyono (dalam Ahmad 2015:155).

\section{HASIL DAN PEMBAHASAN}

Hasil rata-rata persentase dari 2 item pertanyaan indikator pelaksanaan kewenangan pemerintahan, maka yang didapatkan hasil rata-rata persentase $73,5 \%$ jadi, dapat ditarik kesimpulan bahwa pada indikator ini berada dalam kategori " baik". Rekapitulasi pelaksanaan otonomi desa Rata-rata persentase dari 7 item pertanyaan indikator tipe kewenangan dan pelaksanaan otonomi Desa, maka yang didapatkan hasil rata-ratapersentase dari indikator tipe kewenangan adalah $73,5 \%$ dan rata-rata persentase dari indikator pelaksanaan otonomi Desa adalah $68.64 \%$ jadi, dapat ditarik kesimpulan bahwa pada indikator ini berada dalam kategori " baik". Faktor-Faktor yang Mempengaruhi Pelaksanaan Kewenangan dipengaruhi tidak adanya implementasi pembagian Kewenangan Pemerintahan. Rekapitulasi Faktor - Faktor yang Mempengaruhi Pelaksanaan Kewenangan dipengaruhi tidak adanya implementasi pembagian Kewenangan 
Pemerintahan, Dengan mengakumulasikan hasil rata-rata persentase dari 3 item pertanyaan pada indikator Faktor-Faktor yang Mempengaruhi Pelaksanaan Kewenangan dipengaruhi tidak adanya implementasi pembagianKewenangan Pemerintahan, maka didapatkan rata-rata hasil persentase yaitu $72,86 \%$ berada pada kategori " baik".

\section{KESIMPULAN}

Pada bab terdahulu telah diuraikan mengenai hasil penelitian dan pembahasan maka penulis menarik kesimpulan sebagai berikut:

1. Berdasarkan dari hasil oleh kuesioner Pelaksanaan Kewenangan Pemerintahan terhadap Otonomi Desa di Desa Carawali Kecamatan Watang Pulu Kabupaten Sidenreng Rappang rata-rata persentase sebesar $70 \%$ termasuk dalam kategori "Baik".

2. Berdasarkan dari hasil olah kuesioner faktor-faktor yang mempengaruhi pelaksanaan kewenangan dipengaruhi tidak adanya tidak adanya implementasi pembagian kewenangan pemerintahan di Desa Carawali Kecamatan Watang Pulu Kabupaten Sidenreng Rappang rata-rata persentase sebesar $71 \%$ termasuk dalam kategori "Baik".

\section{E. REFERENSI}

Ahmad, J. (2015). Metode Penelitian Administrasi Publik, Yogjakarta: Gava Media.

Haryanto.(2006). Desentralisasi, Otonomi Desa, Implementasi Pembagian Kewenangan, Fakultas Sastra dan Seni Rupa UNS.

Hari Sabarno, (2007). Memandu Otonomi Daerah Menjaga Kesatuan Bangsa, Jakarta 13220 : Sinar Grafika.

Sugiyono.(2011). Statistika Untuk Penelitian. Cetakan Kedelapanbelas. Bandung: CV Alfabeta.

(2009). Metode Penelitian Kuantitatif dan Kualitatif.CV.Alfabeta: Bandung.
...(2014). Metode Penelitian Pendidikan Pendekatan Kuantitatif dan Kualitatif. Bandung: Alfabet

\begin{tabular}{crr} 
Syafiie, Inu & \multicolumn{2}{c}{ Kencana.(2005). Sistem } \\
Administrasi & Negara & Republik \\
Indonesia & (SANRI).Jakarta: & Bumi \\
Aksara & &
\end{tabular}

Muhadam Labolo. (2006). Memahami IImu Pemerintahan.Jakarta : PT. Raja Grafindo Persada.

Widjaja, HAW. (2003). Titik Berar otonomi Daerah Pada Daerah Tingkat II, Jakarta: PT. Rajawali Pers

(2008). Otonomi Desa Merupakan Otonomi Yang Asli, Bulat Dan Utuh, .Jakarta: Raja Grafindo Persada.

Ndraha. (2005). Teori Budaya Organisasi. Jakarta: PT. Rineka Cipta.

Maria, SR. (2002). Dasar-Dasar Public Relations Teori dan Praktik. Jakarta: Gramedia Widiasarana Indonesia

Philipus M. Hadjon, dkk. (2005). Hukum Administrasi Negara.Gadjah Mada University Press :Yogyakarta.

Ndraha, Taliziduhu. (2011). Kybernologi ( IImu Pemeri1ntahan Baru). Rineke Cipta: Jakarta.

Kamal Hidjaz.(2010). Efektivitas Penyelenggaraan Kewenangan Dalam Sistem Pemerintahan Daerah Di Indonesia. Pustaka Refleksi : Makasar.

Miriam Budiardjo. (2008). Dasar-Dasar IImu Politik.Gramedia Pustaka Utama: Jakarta.

Ranciscus Van Ylst. (2008). Epistemologi IImu Pemerintahan.Disertasi. UI: Depok.

Ridwan HR. (2013). Hukum Administrasi Negara. PT Raja Grafindo Persada: Jakarta.

Sarundajang, S. H. (2012). Babak Baru Sistim Pemerintahan. Kata Hasta Pustaka : Jakarta

Nur Basuki Minarno. (2010). Penyalahgunaan Wewenang Dalam 
Pengelolaan Keuangan Daerah. Laksbang Mediatama: Surabaya.

http://www.negarahukum.com/hukum/pengert ian-kewenangan.htm,

https://www.google.com/search?q=Pengertia $n+$ kewenangan

Undang-Undang No. 6 Tahun 2014

Undang-Undang No. 23 Tahun 